\title{
Penerapan Model Pembelajaran Collaborative Learning Untuk Meningkatkan Hasil Belajar Bahasa Inggris Materi Descriptive Text
}

\author{
Darmiati \\ ( Guru SMA Negeri 7 Aceh Barat Daya Provinsi Aceh)
}

\begin{abstract}
Abstrak - Hasil ulangan harian yang dilaksanakan pada awal semester 1 tahun pelajaran 2019/2020 dapat diketahui bahwa tingkat ketuntasan belajar siswa baru mencapai 30,89\%. Nilai rata-rata kelas yang diperoleh masih di bawah KKM yang ditetapkan sebesar 70, yaitu baru mencapai 60. Atas dasar hal tersebut maka siswa kelas X.IPS.2 belum mencapai ketuntasan belajar. Penelitian tindakan kelas ini dilaksanakan selama 3 bulan, mulai dari bulan September 2019 sampai dengan bulan November 2019 dengan subyek penelitiannya adalah siswa kelas X.IPS.2 SMA Negeri 7 Aceh Barat Daya yang berjumlah 26 siswa yang terdiri dari 17 siswa laki-laki dan 9 siswi perempuan. Dalam penelitian ini pengumpulan data menggunakan teknik tes dan non tes. Tes tulis digunakan pada akhir siklus I dan siklus II. Sedangkan Teknik non tes meliputi teknik observasi dan dokumentasi. Observasi digunakan pada saat pelaksanaan penelitian tindakan kelas untuk melihat hasil belajar siswa pada siklus I dan siklus II. Berdasarkan penelitian yang telah dilakukan maka dapat diambil beberapa kesimpulan di antaranya; 1) Penerapan pembelajaran model kolaboratif learning dapat meningkatkan hasil belajar siswa materi descriptive text pelajaran Bahasa Inggris pada siswa kelas X.IPS.2 Semester 1 di SMA Negeri 7 Aceh Barat Daya. Pada Pada akhir siklus I, siswa yang mencapai ketuntasan belajar sebanyak 57,69\% (15 siswa), dan siswa yang belum tuntas sebanyak 42,31\% (11 siswa), sedangkan pada akhir siklus II, sebanyak 96,15\% (25 siswa) dan sebanyak 3,85\% (1 siswa) belum mencapai ketuntasan belajar. 2) Adapun hasil non tes pengamatan proses belajar menunjukkan perubahan siswa lebih aktif selama proses pembelajaran berlangsung dan suasana kelas pun menjadi riang dan tidak monoton lagi.
\end{abstract}

Kata Kunci: Model Pembelajaran Kolaboratif Learning, hasil belajar

\section{Pendahuluan}

Pemerintah telah melaksanakan berbagai program dan menetapkan berbagai kebijakan untuk meningkatkan mutu pendidikan. Namun dalam kenyataannya hasil belajar siswa masih rendah, hal ini terbukti masih banyak siswa yang Nilai ujian sekolah kurang ditingkat sekolah menengah Atas. Sekolah Menengah Atas (SMA) Negeri 7 Aceh Barat Daya, yang letaknya di Gampong Pante Rakyat Kecamatan Babahrot, Kabupaten Aceh Barat Daya dengan jumlah gurunya sudah memadai sebanyak 40 orang yang terdiri dari 19 orang guru PNS dan 9 orang guru kontrak dan 12 orang guru honor serta jumlah siswa sebanyak 436 orang. Terdiri dari 16 rombel, penulis salah seorang guru di sekolah tersebut mengajar di kelas X.IPS.2, ,X.IPS.3, XI.IPA.1, XII.IPA.2 dan XII.IPS.2. Dari semua kelas yang penulis mengajar, hanya kelas X.IPS.2 yang hasil belajarnya masih rendah dalam pelajaran Bahasa Inggris khusunya materi descriptive text, dengan jumlah 26 orang siswa terdiri dari 9 orang siswa perempuan dan 17 orang siswa laki-laki. Menurut pengamatan penulis dari 26 orang siswa hanya 10 orang siswa yang rata-rata tuntas atau hasil belajarnya baik, sedangkan lainnya pencapaian hasil belajarnya masih rendah, terutama pelajaran bahasa Inggris khususnya materi descriptive text dan terbukti masih banyak siswa yang harus diremedialkan.

Berdasarkan hasil ulangan harian yang dilaksanakan pada awal semester 1, dapat diketahui bahwa tingkat ketuntasan siswa baru mencapai 30,43\%. Nilai rata-rata kelas yang diperoleh masih di bawah KKM yang ditetapkan sebesar 70, Atas dasar hal tersebut maka siswa kelas X.IPS.2 belum mencapai ketuntasan belajar. 
Jurnal Nasional Komputasi dan Teknologi Informasi

Vol. 3 No. 1, April 2020

P-ISSN 2620-8342

E-ISSN 2621-3052

Hal ini disebabkan oleh berbagai persoalan diantaranya guru mengajar masih menggunakan metode, model, dan alat peraga yang belum relevan. Sehingga membuat siswa pasif, maka hasil belajarnya rendah. Sedangkan harapan penulis semua siswa bernilai baik dan tercapai KKM yang telah di tetapkan 70. Dengan demikian penulis perlu menggunakan media dan model pembelajaran yang relevan agar hasil belajar siswa meningkat. Karena melalui penggunaan model pembelajaran yang relevan dapat meningkatkan motivasi belajar siswa yang pada gilirannya dapat meningkatkan hasil belajar siswa dalam semua pelajaran terutama pelajaran bahasa inggris yang merupakan bahasa Internasional. Atas dasar itulah penulis ingin mengkaji lebih mendalam terhadap masalah ini melalui suatu penelitian, sehingga judul penelitian tindakan kelas ini penulis tetapkan sebagai berikut: "Penerapan Model Pembelajaran Kolaboratif Learning Untuk Meningkatkan Hasil Belajar Bahasa Inggris Materi Descriptive Text Pada Siswa Kelas X.IPS.2 SMA Negeri 7 Aceh Barat Daya

Berdasarkan latar belakang masalah di atas, maka yang menjadi rumusan masalah dalam penelitian ini antara lain:

1. Apakah penerapan model pembelajaran Kolaboratif Learning dapat meningkatkan hasil belajar siswa kelas X.IPS.2 SMA Negeri 7 Aceh Barat Daya materi descriptive text pelajaran Bahas Inggris?

2. Apakah dengan menggunakan model pembelajaran Kolaboratif Learning dapat meningkatkan aktifitas belajar siswa kelas X.IPS.2 SMA Negeri 7 Aceh Barat Daya materi descriptive text pelajaran Bahasa Inggris?

Dari rumusan masalah di atas, maka yang menjadi tujuan penelitian ini adalah:

1. Untuk meningkatkan hasil belajar siswa kelas X.IPS.2 SMA Negeri 7 Aceh Barat Daya materi descriptive text pelajaran Bahasa Inggris dengan menggunakan model pembelajaran Kolaboratif Learning

2. Untuk meningkatkan aktifitas belajar siswa kelas X.IPS.2 SMA Negeri 7 Aceh Barat Daya materi descriptive text pelajaran Bahasa Inggris dengan menggunakan model pembelajaran Kolaboratif Learning

Hasil penelitian ini hendaknya bermanfaat bagi semua pihak dalam rangka meningkatkan mutu pendidikan terutama bagi Guru Sebagai motivasi untuk meningkatkan keterampilan memilih strategi pembelajaran yang bervariasi dan dapat memperbaiki sistem pembelajaran sehingga memberikan layanan yang terbaik bagi siswa dan Siswa agar menjadi lebih tertarik dan berminat terhadap belajar pelajaran Bahasa Inggris karena siswa dilibatkan secara aktif dalam proses pembelajaran.

\section{Tinjauan Pustaka}

Pembelajaran kolaboratif (Colaborative Learning) merupakan model pembelajaran yang menerapkan paradigma baru dalam teori-teori belajar[1][2]. Pendekatan ini dapat digambarkan sebagai suatu model pembelajaran dengan menumbuhkan para siswa untuk bekerja sama dalam kelompok-kelompok kecil untuk mencapai tujuan yang sama. Pendekatan kolaboratif bertujuan agar siswa dapat membangun pengetahunnya melalui dialog, saling membagi informasi sesama siswa dan guru sehingga siswa dapat meningkatkan kemampuan mental pada tingkat tinggi[9]. Model ini digunakan pada setiap mata pelajaran terutama yang mungkin berkembangkan sharing of information di antara siswa.

Belajar kolaboratif digambarkan sebagai suatu model pengajaran yang mana para siswa bekerja sama dalam kelompok-kelompok kecil untuk mencapai tujuan yang sama[4]. Hal yang perlu diperhatikan dalam kegiatan belajar kolaboratif, para siswa bekerja sama menyelesaikan masalah yang sama, dan bukan secara individual menyelesaikan bagian-bagian yang terpisah dari masalah tersebut. Dengan demikian, selama berkolaborasi para siswa bekerja sama membangun pemahaman dan konsep yang sama menyelesaikan setiap bagian dari masalah atau tugas tersebut. Pendekatan kolaboratif dipandang sebagai proses membangun dan mempertahankan konsepsi yang sama tentang suatu masalah. Dari sudut pandang ini, model belajar kolaboratif menjadi efisien karena para 
Jurnal Nasional Komputasi dan Teknologi Informasi

Vol. 3 No. 1, April 2020

P-ISSN 2620-8342

E-ISSN 2621-3052

anggota kelompok belajar dituntut untuk berpikir secara interaktif. Para ahli berpendapat bahwa berpikir bukanlah sekedar memanipulasi objek-objek mental, melainkan juga interaksi dengan oran glain dan dengan lingkungan[5].

Dalam kelas yang menerapkan model kolaboratif, guru membagi otoritas dengan siswa dalam berbagai cara khusus. Guru mendorong siswa untuk menggunakan pengetahun mereka, menghormati rekan kerjanya, dan memfokuskan diri pada pemahaman tingkat tinggi. Peran guru dalam model pembelajaran kolaboratif adalah sebagai mediator. Guru menghubungkan informasi baru terhadap pengalaman siswa dengan proses belajar di bidang lain, membantu siswa menentukan apa yang harus dilakukan jika siswa mengalami kesulitan, dan membantu mereka belajar tentang bagaimana caranya belajar. Lebih dari itu, guru sebagai mediator menyesuaikan tingkat informasi siswa dan mendorong agar siswa memaksimalkan kemampuannya untuk bertanggung jawab atas proses belajar mengajar selanjutnya.

Sebagai mediator, guru menjalani tiga peran, yaitu berfungsi sebagai falisitator, model, dan pelatih. Sebagai fasilitator, guru menciptakan lingkungan dan kreativitas yang kaya guna membantu siswa membangun pengetahunnya. Dalam rangka menjankan peran ini, ada tiga hal pula yang harus dikerjakan. Pertama, mengatur lingkungan fisik, termasuk pengaturan tata letak perabot dalam ruangan serta persediaan berbagai sumber daya dan peralatan yang dapat membantu proses belajar mengajar siswa. Kedua, menyediakan lingkungan sosial yang mendukung proses belajar siswa, seperti mengelompokkan siswa secara heterogen dan mengajak siswa mengembangkan struktur sosial yang mendorong munculnya perilaku yang sesuai untuk kolaborasi antarsiswa. Ketiga, guru memberikan tugas memancing munculnya interaksi antarsiswa dengan lingkungan fisik maupun sosial di sekitarnya. Dalam hal ini, guru harus mampu memotivasi siswa.

Peran sebagai model dapat diwujudkan dengan cara membagi pikiran tentang suatu hal (thinking aloud) atau menunjukkan pada siswa tentang bagaimana melakukan sesuatu secara bertahap (demonstrasi)[6]. Di samping itu, menunjukkan pada siswa bagaimana cara berpikir sewaktu melalui situasi kelompok yang sulit dan melalui masalah komunikasi adalah sama pentingnya dengan mencontohkan bagaimana cara membuat perencanaan, memonitor penyelesaian tugas, dan mengukur apa yang sudah dipelajari. Peran guru sebagai pelatih mempunyai prinsip utama, yaitu menyediakan bantuan secukupnya pada saat siswa membutuhkan sehingga siswa tetap memegang tanggung jawab atas proses belajar mereka sendiri. Hal ini dilakukan dengan memberikan petunjuk dan umpan balik, mengarahkan kembali usaha siswa, serta membantu mereka menggunakan strategi tertentu. Salah satu ciri penting dari kelas yang menerapkan model pembelajaran kolaboratif adalah siswa tidak dikotak-kotakan berdasarkan kemampuannya, minatnya, ataupun karakteristik lainnya. Pengkotakan tersebut dinilai menghambat munculnya kolaborasi dan mengurangi kesempatan siswa untuk belajar bersama siswa lain. Dengan demikian, semua siswa dapat belajar dari siswa lain dan tidak ada siswa yang tidak mempunyai kesempatan untuk memberikan masukan dan menghargai masukan yang diberikan orang lain.

Model kolaboratif dapat digambarkan sebagai berikut. Ketika terjadi kolaborasi, semua siswa aktif. Mereka saling berkomunikasi secara alami. Dalam sebuah kelompol yang terdiri atas 4 sampai 6 siswa, di sana guru sudah membuat rancangan agar siswa yang satu dengan yang lain bisa berkolaborasi. Dalam kelompok yang sudah ditentukan oleh guru, fasilitas yang ada pun diusahakan anak mampu berkolaborasi. Misalnya, dalam kelompok yang terdiri atas 4 sampai 6 tersebut seorang guru hanya menyiapkan 2 sampai 3 kotak alat mewarna yang dipakai secara bergantian. Dengan harapan, setiap siswa bisa bekomunikasi satu dengan yang lainnya. Dengan komunikasi aktif antar siswa, akan terjalin hubungan yang baik dan saling menghargai. Alat tersebut bukan milik pribadi, melainkan sudah menjadi milik bersama. Setiap siswa tidak merasa memiliki secara pribadi, tetapi bisa dipakai bersama. Pada saat yang sama mempunyai keinginan untuk memakainya maka akan terjadi komunikasi yang alami dengan penggunaan santun bahasa. Dalam kondisi seperti ini seorang guru hanya mengamati cara kerja siswa dan cara berkomunikasi serta menjadi pembimbing saat siswa memerlukan bantuan. 


\subsection{Hasil Belajar}

Di dalam istilah hasil belajar, terdapat dua unsur di dalamnya, yaitu unsur hasil dan unsur belajar. Hasil merupakan suatu hasil yang telah dicapai pebelajar dalam kegiatan belajarnya (dari yang telah dilakukan,dikerjakan, dan sebagainya)[7]. Dari pengertian ini maka hasil belajar adalah penguasaan pengetahuan / keterampilan yang dikembangkan oleh mata pelajaran, lajimnya ditunjukkan dengan nilai tes atau angka nilai yang diberikan oleh guru.Belajar itu sebagai suatu proses perubahan tingkah laku, atau memaknai sesuatu yang diperoleh. Akan tetapi apabila kita bicara tentang hasil belajar, maka hal itu merupakan hasil yang telah dicapai oleh si pebelajar.

Istilah hasil belajar mempunyai hubungan yang erat kaitannya dengan prestasi belajar. Sesungguhnya sangat sulit untuk membedakan pengertian prestasi belajar dengan hasil belajar. Ada yang berpendapat bahwa pengertian hasil belajar dianggap sama dengan pengertian prestasi belajar. Akan tetapi lebih dahulu sebaiknya kita simak pendapat yang mengatakan bahwa hasil belajar berbeda secara prinsipil dengan prestasi belajar. Hasil belajar menunjukkan kualitas jangka waktu yang lebih panjang, misalnya satu cawu, satu semester dan sebagainya. Sedangkan prestasi belajar menunjukkan kualitas yang lebih pendek, misalnya satu pokok bahasan, satu kali ulangan harian dan sebagainya.

Hasil Belajar adalah keberhasilan murid dalam mempelajari materi pelajaran di sekolah yang dinyatakan dalam bentuk nilai atau skor dari hasil tes mengenai sejumlah pelajaran tertentu[8]. Hasil belajar adalah hasil yang dicapai oleh tenaga atau daya kerja seseorang dalam waktu tertentu[7]. Sejak awal dikembangkannya ilmu pengetahuan tentang perilaku manusia, banyak dibahas mengenai bagaimana mencapai hasil belajar yang efektif. Para pakar dibidang pendidikan dan psikologi mencoba mengidentifikasikan faktor-faktor yang mempengaruhi hasil belajar. Dengan diketahuinya faktor-faktor yang berpengaruh terhadap hasil belajar, para pelaksana maupun pelaku kegiatan belajar dapat memberi intervensi positif untuk meningkatkan hasil belajar yang akan diperoleh.

\subsection{Model kolaboratif learning Meningkatkan Hasil Belajar Siswa}

Beberapa hasil penelitian tentang penerapan model pembelajaran kolaboratif learning memiliki dampak positif terhadap hasil belajar siswa. Selain dapat meningkatkan hasil belajar, siswa juga mampu menumbuhkan hasil belajar berpikir, kerjasama dan mengembangkan sikap sosial siswa. Muhibbah (2009) menyatakan bahwa penerapan model kolaboratif learning dapat memberikan pengaruh yang baik terhadap hasil belajar siswa, siswa yang diajarkan dengan model kolaboratif learning mempunyai nilai rata-rata yang lebih tinggi dibandingkan siswa yang diajar dengan model tanya jawab.

Adapun hipotesis dalam penelitian ini adalah" Penerapan Model Pembelajaran Kolaboratif Learning dapat meningkatkan hasil belajar Bahasa Inggris materi descriptive text pada siswa kelas X.IPS.2 SMA Negeri 7 Aceh Barat Daya

\section{Metode Penelitian}

Penelitian dilaksanakan selama 3 bulan, mulai dari bulan September sampai dengan bulan November 2019. di kelas X..IPS.2 SMA Negeri 7 Aceh Barat Daya dengan subyek penelitian siswa kelas X.IPS.2 SMA Negeri 7 Aceh Barat Daya yang berjumlah 26 siswa yang terdiri dari 17 siswa laki-laki dan 9 siswi perempuan. Sumber data dalam penel;itian ini adalah siswa. Data yang dikumpulkan dari siswa meliputi data hasil tes dan non tes yang meliputi observasi dan dokumentasi.

Analisis data yang digunakan dalam penelitian ini adalah teknik analisis dekskriptif, yang meliputi:Analisis deskriptif komparatif perkembangan kognitif dengan cara membandingkan kemampuan belajar siswa pada siklus I dengan siklus II. Dan analisis deskriptif kualitatif observasi dengan cara membandingkan hasil observasi dan refleksi pada siklus I dan siklus II. 
Jurnal Nasional Komputasi dan Teknologi Informasi

Vol. 3 No. 1, April 2020

P-ISSN 2620-8342

E-ISSN 2621-3052

\section{Hasil Dan Pembahasan}

\subsection{Hasil Penelitian}

Dari hasil tes siklus I, menunjukkan bahwa hasil yang mencapai nilai A (sangat baik) adalah 4 siswa (15,38\%), sedangkan yang mendapat nilai B (baik) adalah 4 siswa atau $(15,38 \%)$, sedangkan dari jumlah 26 siswa yang masih mendapatkan nilai C (cukup) sebanyak 8 siswa (30,77\%), sedangkan yang mendapat nilai D (kurang) sebanyak 7 siswa (26,92\%), sedangkan yang mendapat nilai D (sangat kurang)masih ada 3 siswa (11,54 \%). Berdasarkan ketuntasan belajar siswa dari sejumlah 26 siswa terdapat 15 atau 57,69\% yang sudah mencapai ketuntasan belajar. Sedangkan 11 siswa atau $42,31 \%$ belum mencapai ketuntasan

Berdasarkan hasil tindakan siklus II dapat diketahui bahwa yang mendapatkan nilai sangat baik (A) adalah $26,92 \%$ atau 7 siswa, sedangkan yang terbanyak yaitu yang mendapat nilai baik (B) adalah 38,46\% atau 10 siswa. Dan yang mendapat nilai C (cukup) adalah 30,77\% atau sebanyak 8 siswa. Sedangkan yang mendapat nilai D (kurang) masih ada 1 siswa atau 3,85\% dan E tidak ada. Berdasarkan ketuntasan belajar diketahui bahwa siswa yang mencapai ketuntasansebanyak 25 siswa $(96,15 \%)$ yang berarti sudah ada peningkatan dibandingkan pada siklus I

Refleksi dilakukan oleh peneliti dengan observer seatelah siklus II berakhir. Dari refleksi menunjukkan bahwa pelaksanaa pembelajaran siklus II relatif sangat baik dari pada pelaksaan pembelajaran siklus I. Hal tersebu dapat dilihat dari peningkatan rata rata nilai tes pada tiap pertemuan,

Tabel Perbandingan Hasil Nilai Tes pra Siklus, Siklus I dan Siklus II

\begin{tabular}{|c|c|c|c|c|}
\hline \multirow{2}{*}{ No } & \multirow{2}{*}{ Hasil Tes } & \multicolumn{3}{|c|}{ Jumlah Siswa yang Berhasil } \\
\hline & & Prasiklus & Siklus I & Siklus II \\
\hline 1 & $90-100 \quad(\mathrm{~A})$ & - & 4 & 7 \\
\hline 2 & $80-89 \quad(\mathrm{~B})$ & 3 & 4 & 10 \\
\hline 3 & $70-79$ & 7 & 7 & 8 \\
\hline 4 & $51-69$ & 9 & 8 & 1 \\
\hline 5 & $<50$ & 7 & 3 & - \\
\hline \multicolumn{2}{|c|}{ Jumlah } & 26 & 26 & 26 \\
\hline
\end{tabular}

\subsection{Pembahasan}

Hasil antara siklus I dan siklus II ada perubahan secara siknifikan, hal ini di tandai dengan meningkatnya jumlah siswa yang mencapai ketuntasan belajar. Dari Hasil tes siklus II ternyata lebih baik disbanding dengan tingkat ketuntasan belajar siswa pada siklus I. Dengan melihat hasil tes siklus I dan siklus II ada peningkatan yang signifikan baik dari ketuntasan maupun hasil perolehan nilai rata rata kelas. Dari sejumlah 26 siswa keseluruhan masih ada satu siswa yang belum mencapai ketuntasan hal ini memang siswa tersebut harus mendapat pembinaan khusus, namun demikian siswa tersebut sngat aktif dan bergairah dalam KBM. Sehingga dapat disimpulkan bahwa me lalui penerapan model pembelajaran kolaboratif learning dapat meningkatkan hasil belajar Bahasa Inggris materi deskcriptive text.

\section{Kesimpulan}

Berdasarkan penelitian ini dapat diambil kesimpulan sebagai berikut:

1. Penerapan pembelajaran model pembelajaran Kolaboratif Learning dapat meningkatkan hasil belajar siswa materi descriptive text pelajaran Bahasa inggris pada siswa kelas X.IPS.2 Semester 1 di SMA Negeri 7 Aceh Barat Daya.. Pada akhir siklus I, siswa yang mencapai ketuntasan belajar sebanyak 57,69\% (15 siswa), dan siswa yang belum tuntas sebanyak 42,31\% (11 siswa), sedangkan pada akhir siklus II, sebanyak 96,15\% (25 siswa) dan sebanyak 3,85\% (1 siswa) belum mencapai ketuntasan belajar. 
Jurnal Nasional Komputasi dan Teknologi Informasi

Vol. 3 No. 1, April 2020

P-ISSN 2620-8342

E-ISSN 2621-3052

2. Adapun hasil non tes pengamatan proses belajar menunjukkan perubahan siswa lebih aktif selama proses pembelajaran berlangsung dan suasana kelas pun menjadi riang dan tidak menoton lagi

Berdasarkan hasil penelitin:dan pembahasan perlu kiranya disarankan

1. Disarankan kepada guru agar tidak hanya menerapkan atau menggunakan metode ceramah dan mencatat saja, akan tetapi guru juga perlu menggunakan model atau metode pembelajaran kooperatif dengan menggunakan model pembelajaran Kolaboratif Learning untuk membangkitkan minat belajar siswa dan memotivasi siswa dalam belajar.

2. Perlu mengatur waktu yang baik terhadap pelaksanaan model pembelajaran Kolaboratif Learning, sehingga siswa benar-benar bisa memanfaatkan waktu untuk mengembangkan ide-ide dan memahami pelajaran yang dipelajari.

\section{Daftar Pustaka}

[1] Arikunto, Suharsimi. 1993. Dasar-dasar Evaluasi Pendidikan. Jakarta: Bina Aksara.

[2] Muhibbah, 2009. Model pembelajaran L. Jakarta: Erlangga

[3] Marimba. 1978. Metodologi Penelitian Pendidikan. Jakarta. Rineksa Cipta. orang tua. Cet -4 Jakarta: PT gramedia

[4] Nawawi 1981 Administrasi Pendidikan. Jakarta PT Gunung Agung

[5] Rostiyah N.K 2001 Strategi belajar Mengajar. Jakarta. Rineka Cipta

[6] Sadly. 1977. Analisis Butir Tes. Surabaya: Universitas Press.

[7] Soetomo 1993.Metodelogi penelitian, CV Rajawali. Jakarta

[8] T. A. Hasan Husein. 2003, Macam-Macam Metode Pembelajaran, Jakarta : Erlangga

[9] Zulfan and Baihaqi, "Aceh Serune Kale and Rapai Ethnic Musical Instrument Preservation Method Based on Two-Dimensional Multimedia Animation," J. Phys. Conf. Ser., vol. 1232, p. $12027,2019$. 